\title{
An interactive conundrum: Constructs of interactivity and learning theory
}

\author{
Rod Sims \\ Southern Cross University
}

\begin{abstract}
The role and function of interactivity within computer enhanced learning is undergoing increased scrutiny. Through a reappraisal of learning theories in terms of their implications for interactivity and identifying the major interactive constructs, this paper provides a context for better understanding computer based interactivity and achieving its potential for enhancing the learning process.
\end{abstract}

\section{Interactivity in conflict}

In a world of interactive gadgetry, the following opinions succinctly demonstrate the conflicting attitudes toward interactivity and the conundrum that confronts the implementation of computer enhanced learning (CEL) environments.

\begin{abstract}
Computer based instruction provides greater potential for truly interactive instruction than any mediated teaching device to date, excluding in many instances, the human tutor. (Jonassen, 1988:97)

... deconstruction essentially reveals interactivity to be not a conceptual unity, defined in terms of clear distinctions between antithetical terms, but as a fragmented, inconsistent, and rather messy notion encompassing both privileged and marginalised binaries, and the range of meanings in between. (Rose, 1999:48)
\end{abstract}

But who is right? Is interactivity an intrinsic component of CEL, enabling effective and engaging learning experiences, or is it a misnomer, masking processes too complex to be measured by overt response-feedback mechanisms?

I argue that a conundrum exists because the perceived advantage of interactivity in CEL is based on its equivalence to real life learner-learner or teacher-learner communication. But can (or should) computer based 
applications attempt to replicate this level of communication? The evolution of educational technology has been reinforced by rhetoric (from both manufacturers and developers) that computers are inherently interactive and therefore beneficial, especially to learning. In reality however, the interactivity demonstrated is frequently little more than mouse clicks and generalised, repetitive, non-adaptive feedback. And while overtly interactive, to what extent do threaded discussions and so called learning communities contribute to interactivity in web based environments?

Given the current interest in interactive constructs (Sims, 1997; Aldrich, Rogers \& Scaife, 1998) contrasted by the argument that interactive and interactivity lack "denotive value" (Rose, 1999), it is therefore important to reassess not only the notion of interactivity but its role in enhancing the learning process in its various forms. To better understand this role, this paper revisits the relationships between interactive constructs and learning theories, proposing a classification that substantiates interactivity as a viable mechanism to support learning. Using this framework, the discussion reassess how these interactive constructs might be applied to contemporary forms of CEL applications, including online initiatives, and provides a research framework for an in depth investigation of interactivity. In developing this argument, much of the research is based on stand alone CEL environments (i.e. human:computer interactions); however, the conclusions drawn are equally relevant to computer mediated (online) human-human interactions.

\section{From learning theory to interactivity}

\section{Interactive prescriptions}

The relationship between how we learn and the interactions which support that learning can be traced as far back into history as we might wish to pursue. However, if we focus specifically on the current century, there are numerous, varied and evolving approaches to learning which can be assessed in terms of their implications for CEL environments and the associated interactive constructs. For the purposes of this section, the term interactivity refers to those functions and/or operations made available to the learner to enable them to work with content material presented in a computer based environment. The later discussion will expand on this definition.

Texts based generally on learning theories separate the work of behavioural, cognitive and contemporary theorists (e.g. Bower \& Hilgard, 1981), while those more focused on the educational technology field offer a 
more specialised analysis. For example, Romiszowski (1986) acknowledges that one's particular philosophical position will influence the structure of learning activities, differentiating the Humanist (with an emphasis on useful content), Behaviourist (emphasising outcomes), Cognitivist and Developmental (emphasising the process) and Cybernetic (emphasising the system) approaches. More recently, Kearsley (1999) compiled the Theory into Practice database, documenting an extensive range of learning theories, concepts and domains. From my synthesis of these theories, a process which identified the major focus of the theoretical position, the means by which it might be implemented in a learning environment and the likely interactive constructs which would be manifested in a CEL environment, I have derived four dimensions linking the prescriptions of interactivity from those theoretical positions.

In presenting these dimensions, it is argued that learning should not be linked to any single strategy or intervention, but viewed as a complex interaction between circumstances, conditions, environment, motivation and culture. While no one theory or paradigm can explain learning completely, this analysis does provide a framework and foundation for considering the constructs of interactivity in the context of CEL.

\section{Deriving interactive constructs}

The following dimensions are by no means meant to assign an interactive element to any one theoretical position, but rather to demonstrate how an assessment of learning theory can reinforce the potential for implementing appropriate interactive strategies. In summary, the four major dimensions identified can be characterised by:

- Learners - the who of the learning process

- Content - the what of the learning process

- Pedagogy - the how of the learning process

- Context - the when and where of the learning process

Within this framework, a set of focus points in relation to interactivity are also identified to further differentiate their relation to the specific learning activity. While beyond the scope of this paper, Reeves (1999) points to an additional dimension - whether the CEL environment is one which learners will learn from (instructivist) or one they will learn with (constructivist). 


\section{Interactivity and learners}

The details provided in Table 1 identify those learning theories that place specific focus on the learner, and that by examining this focus particular interactive constructs can be derived. By considering the Learner dimension, developers may be able to create applications that are more adaptive to the specific characteristics of the target population. For example, providing certain orienting sequences or ensuring the learner is clear of their role in the educational process. This is also consistent with the prescriptions of criteria for effective user interface design (Mandel, 1997).

\begin{tabular}{|c|c|c|}
\hline Focus & Interactive Constructs & Related Theories \\
\hline $\begin{array}{l}\text { Goal } \\
\text { Navigation; } \\
\text { Exploration }\end{array}$ & $\begin{array}{l}\text { - Select navigational paths } \\
\text { - Retrieve appropriate content } \\
\text { - Move within a simulated } \\
\text { environment } \\
\text { - Explore conditions of rule } \\
\text { operation } \\
\text { - Compare results }\end{array}$ & $\begin{array}{l}\text { Sign Learning (Tolman, 1932); } \\
\text { Constructivist (Bruner, 1966); } \\
\text { Information Pick Up (Gibson, } \\
\text { 1966); Structural Learning } \\
\text { (Scandura, 1973); Androgogy } \\
\text { (Knowles, 1984); Adult Learning } \\
\text { (Cross, 1981); Soar (Newell, 1990) }\end{array}$ \\
\hline $\begin{array}{l}\text { Making } \\
\text { Selections }\end{array}$ & $\begin{array}{l}\text { - Access manageable pieces of } \\
\text { material } \\
\text { - Modify content structure }\end{array}$ & $\begin{array}{l}\text { Information Processing (Miller, } \\
\text { 1956) }\end{array}$ \\
\hline Tools & - Access help or support tools & $\begin{array}{l}\text { Cognitive Dissonance (Festinger, } \\
\text { 1957) }\end{array}$ \\
\hline $\begin{array}{l}\text { Control: to } \\
\text { Construct or } \\
\text { Deconstruct }\end{array}$ & $\begin{array}{l}\text { - Construct or modify } \\
\text { properties of and/or } \\
\text { relationships between } \\
\text { learning objects } \\
\text { - Create personal narratives }\end{array}$ & $\begin{array}{l}\text { Gestalt (Wertheimer, 1959); } \\
\text { Lateral Thinking (de Bono, 1967); } \\
\text { Experiential (Rogers, 1969); Dual } \\
\text { Coding (Paivio, 1986); Levels of } \\
\text { Processing (Craik \& Lockhart, } \\
\text { 1972); Script (Schank, 1982); } \\
\text { Component Display (Merrill, } \\
\text { 1983); Cognitive Flexibility } \\
\text { (Spiro, Feltovich, Jacobson \& } \\
\text { Coulson, 1992) }\end{array}$ \\
\hline $\begin{array}{l}\text { Prompt for } \\
\text { engagement }\end{array}$ & - Generate original responses & $\begin{array}{l}\text { Originality (Maltzman, 1960); } \\
\text { Constructivist (Bruner, 1960); }\end{array}$ \\
\hline $\begin{array}{l}\text { Scaffolding; } \\
\text { Modelling }\end{array}$ & $\begin{array}{l}\text { - Assemble or disassemble } \\
\text { support tools as required } \\
\text { - Adapt dynamic scaffolding } \\
\text { according to individual } \\
\text { schema } \\
\text { - Access exemplars to support } \\
\text { knowledge acquisition }\end{array}$ & $\begin{array}{l}\text { Constructivist (Bruner, 1966); } \\
\text { Social Learning (Bandura, 1971); } \\
\text { Script (Schank, 1982) }\end{array}$ \\
\hline
\end{tabular}

Table 1: Interactive constructs for learners 


\section{Interactivity and content}

The content or subject matter presented to learners is a second dimension that can be derived from learning theories and paradigms, as represented in Table 2. While the structuring of the content sequences is closely associated with the pedagogical dimension, the level and depth of content and the underlying information and presentation design is critical to the overall interactive experience. It is predicted that more detailed emphasis on the way in which the content elements, and the media used to represent them, are linked to the underlying rationale for the application will result in more effective interactions and consequent learning. This is well demonstrated by the dimensions of design identified by Shedroff (1994).

A tangential element of this dimension is the importance of including learner representatives in the design process, as they are the group who can verify the effectiveness of the interactive experience in terms of participation, engagement and learning outcomes.

\begin{tabular}{|c|c|c|}
\hline Focus & Interactive Constructs & Related Theories \\
\hline $\begin{array}{l}\text { The more } \\
\text { the better }\end{array}$ & - Present questions frequently & $\begin{array}{l}\text { Connectionism (Thorndike, } \\
\text { 1913) }\end{array}$ \\
\hline Essential & - Ensure interactions implemented & $\begin{array}{l}\text { Contiguity (Guthrie, 1930); } \\
\text { Drive Reduction (Hull, 1943) }\end{array}$ \\
\hline Engagement & $\begin{array}{l}\text { - Integrate meaningful } \\
\text { engagement through access to } \\
\text { different content representations } \\
\text { - Enable the means to control } \\
\text { displayed media elements } \\
\end{array}$ & $\begin{array}{l}\text { Dual Coding (Paivio, 1986), } \\
\text { Levels of Processing (Craik \& } \\
\text { Lockhart, 1972) }\end{array}$ \\
\hline $\begin{array}{l}\text { Content } \\
\text { Dependent }\end{array}$ & $\begin{array}{l}\text { - Vary structural presentation as a } \\
\text { function of content domain } \\
\text { - Enable learner elaboration of } \\
\text { epitomes }\end{array}$ & $\begin{array}{l}\text { Algo-Heuristic (Landa, 1974), } \\
\text { Component Display (Merrill, } \\
\text { 1983); Elaboration (Reigeluth, } \\
\text { 1992) }\end{array}$ \\
\hline Multimedia & $\begin{array}{l}\text { - Enable the means to select media } \\
\text { used to display content } \\
\text { structures } \\
\text { - Enabling access to and } \\
\text { manipulation of content }\end{array}$ & $\begin{array}{l}\text { Symbol Systems (Salomon, } \\
\text { 1979); Dual Coding (Paivio, } \\
\text { 1986); Cognitive Flexibility } \\
\text { (Spiro et al, 1992) }\end{array}$ \\
\hline Minimalist & • Include only necessary content & $\begin{array}{l}\text { GOMS (Card, Moran \& } \\
\text { Newell, 1983); Minimalist } \\
\text { (Carroll, 1990) }\end{array}$ \\
\hline
\end{tabular}

Table 2: Interactive constructs for content 


\section{Interactivity and pedagogy}

As detailed in Table 3, the pedagogical structures that can be associated with CEL applications also suggest certain interactive constructs. This dimension is also critical, as it will determine the extent to which the learner is able to move (navigate), test (explore) and manoeuvre (self pace) through the product. It will also focus on what measures will represent completion; if based on a teaching (instructivist) model, then some form of assessment might be required. If based on a learner (constructivist) model, then completion of the task itself might be the measure of success. The implications are that the instructional design and development process must be extended to adapt for interactivity to maximise engagement - as the learner may often be operating in an independent environment without access to teacher or facilitator support.

\begin{tabular}{|l|l|l|}
\hline Focus & Interactive Constructs & Related Theories \\
\hline $\begin{array}{l}\text { Vary } \\
\text { to learner }\end{array}$ & $\begin{array}{l}\text { Vary as a function of } \\
\text { developmental stage } \\
\text { Vary according to individual } \\
\text { skills } \\
\text { Integrate contextual and socio- } \\
\text { cultural elements }\end{array}$ & $\begin{array}{l}\text { Genetic Epistemology (Piaget, } \\
\text { 1929); Conditions of Learning } \\
\text { (Gagne, 1985); Subsumption } \\
\text { (Ausubel, 1963); General Problem } \\
\text { Solver (Newell \& Simon, 1972); } \\
\text { Androgogy (Knowles, 1984); } \\
\text { Adult Learning (Cross, 1981); } \\
\text { ACT (Anderson, 1976); ATI } \\
\text { (Cronbach \& Snow, 1977); } \\
\text { Triarchic (Sternberg, 1977); }\end{array}$ \\
\hline $\begin{array}{l}\text { Question- } \\
\text { Answer- } \\
\text { Feedback }\end{array}$ & $\begin{array}{l}\text { Adopt a cyclic question } \\
\text { (stimulus), answer (response) } \\
\text { and feedback loop }\end{array}$ & $\begin{array}{l}\text { Operant Conditioning (Skinner, } \\
\text { 1950) }\end{array}$ \\
\hline $\begin{array}{l}\text { Self } \\
\text { pacing }\end{array}$ & $\begin{array}{l}\text { Enable learner control } \\
\text { Enable self testing of } \\
\text { achievement (mastery) }\end{array}$ & $\begin{array}{l}\text { Mathematical (Atkinson, 1972); } \\
\text { Criterion Referenced (Mager, } \\
\text { 1988) }\end{array}$ \\
\hline $\begin{array}{l}\text { Problem } \\
\text { Based }\end{array}$ & $\begin{array}{l}\text { Enable assessment of individual } \\
\text { success } \\
\text { Enable testing and problem } \\
\text { solving of currently held beliefs } \\
\text { or concepts }\end{array}$ & $\begin{array}{l}\text { Experiential (Rogers, 1969); } \\
\text { General Problem Solver (Newell } \\
\text { \& Simon, 1972); Double Loop } \\
\text { (Argyris \& Schon, 1974); Repair } \\
\text { (Brown \& Van Lehn, 1980); } \\
\text { Mathematical Problem Solving } \\
\text { (Schonfield, 1985 }\end{array}$ \\
\hline
\end{tabular}

Table 3: Interactive constructs and pedagogy

\section{Interactivity and context}

The fourth dimension by which learning theories and interactivity may be examined relates to the context in which learning is undertaken (Table 4). In the classroom, learning can range from the abstract to the laboratory 
and simulated environments, which can be replicated on a computer if appropriate. However, attempting to provide a context for learning demands not only the integration of knowledge and information into a specific situation but also enabling the learner to position themselves in that context to understand the situation and purpose of that information.

For example, while a group of army specialists may be taken to a bombing range to practice disarming explosives, recreating the same scenario on a computer is complex because time and space constraints associated with the task are difficult to replicate. One of the challenges therefore, if attempting to develop a CEL environment incorporating a contextual metaphor, is to provide learners with adequate visual cues and support tools to establish a realistic and meaningful learning experience.

\begin{tabular}{|c|c|c|}
\hline Focus & Interactive Exemplars & Related Theories \\
\hline $\begin{array}{l}\text { Contextual, } \\
\text { Situated }\end{array}$ & $\begin{array}{l}\text { - Enable access to people (real or } \\
\text { simulated) to provide } \\
\text { assistance } \\
\text { - Focus on action-consequence } \\
\text { model } \\
\text { - Relate contextual controls } \\
\text { (tools) to support facilities } \\
\text { - Enable social operations r }\end{array}$ & $\begin{array}{l}\text { Functional Literacy (Sticht, 1976); } \\
\text { Social Development (Vygotsky, } \\
\text { 1962); Symbol Systems (Salomon, } \\
\text { 1979); Phenomenography } \\
\text { (Marton, Hounsell \& Entwistle, } \\
\text { 1984); Cognitive Flexibility (Spiro } \\
\text { et al, 1982); Situated (Lave \& } \\
\text { Wenger, 1990) }\end{array}$ \\
\hline $\begin{array}{l}\text { Learning } \\
\text { Styles }\end{array}$ & $\begin{array}{l}\text { Enable learner and program } \\
\text { adaptation strategies }\end{array}$ & $\begin{array}{l}\text { Modes of Learning (Rumelhart \& } \\
\text { Norman, 1978); Multiple } \\
\text { Intelligences (Gardner, 1993) }\end{array}$ \\
\hline
\end{tabular}

Table 4: Interactive constructs for context

\section{A case for reason}

These four dimensions of interactive learning, derived from a wide range of learning theories, support the position that interactivity constructs can be viewed as outcomes from educational research rather than a manifestation of a technological imperative. Therefore it is important not to assume that 'old technology is bad, new technology is good' in the way that Kearsley \& Shneiderman (1999) promote an engagement theory model designed to supersede the attempts of the last three decades to achieve success with CEL applications. Instead there is a case for reason, a case to remind ourselves that it is the theoretical frameworks, which provide a guide for interactivity, that will enable us to achieve success in our teaching and learning endeavours.

Given this potential, the following discussion reviews the classifications of interactivity and demonstrates that a better understanding of the 
interactive process is required in order to maximise engagement within CEL environments. Although many products have been marketed as representing effective applications by the development teams or through competitive awards, the real effectiveness of any application will only be achieved when representatives of the target group praise its worth. How we might achieve this is the purpose for attempting to better understand this interactive conundrum.

\section{Constructs of interactivity}

\section{Revisiting the concept}

In challenging the way educational technology has applied the term interactive to its outputs, it has been suggested that if we cannot define the term, how can we promote it as a determinant of learning...

In recent years, the concept of interactivity has become so firmly entrenched within the discourse of educational computing that it is a truism to say that instructional software is interactive and that interactivity promotes learning, and a kind of heresy to dispute it. (Rose, 1999: 43)

Nevertheless, analyses of interactivity have provided useful perspectives for assessing interactivity through taxonomies (Schwier \& Misanchuck, 1993); levels (Sims, 1997) and dimensions (Aldrich et al, 1998), as expanded in Table 5. Even so, it is acknowledged that further research is required to better understand what is often an ill defined concept, with the aim of "moving the emphasis away from the level of physical interactivity at the interface (ie. button presses and mouse clicks) to a consideration of cognitive interactivity (ie. learning activities which are supported when interacting with the software" (Aldrich et al, 1998:331).

An alternative perspective focusing on narrative and play as a model for interactive endeavours (Plowman, 1996; Sims, 1999) focuses on the strategies which might be implemented to enable the user (learner) to become an integral part of the narrative or story being promoted by the developer. Not only will the learner be offered activities for participation and engagement, but the underlying structure (scaffolding) will ensure they have a clear orientation and sense of purpose for moving within the application, regardless of its explicit structure. In offering this as a potential success factor for interactivity, it augments those issues that must be considered by the development team to include strategies to enable the learner to be integrated into the interactive world as the lead character. 


\begin{tabular}{|c|c|c|}
\hline $\begin{array}{c}\text { Taxonomy of } \\
\text { Interactivity (Schwier } \\
\text { \& Misanchuk, 1993) }\end{array}$ & $\begin{array}{c}\text { Levels of } \\
\text { Interactivity } \\
\text { Sims (1997) }\end{array}$ & $\begin{array}{c}\text { Dimensions of } \\
\text { Interactivity } \\
\text { (Aldrich et al, 1998) }\end{array}$ \\
\hline $\begin{array}{l}\text { Levels } \\
\text { Reactive } \\
\text { Proactive } \\
\text { Mutual } \\
\text { Functions } \\
\text { Confirmation } \\
\text { Pacing } \\
\text { Navigation } \\
\text { Inquiry } \\
\text { Elaboration } \\
\text { Transactions } \\
\text { Keyboard, touch } \\
\text { panel } \\
\text { Pointing device }\end{array}$ & $\begin{array}{l}\text { Levels } \\
\text { Object } \\
\text { Linear } \\
\text { Hierarchical } \\
\text { Support } \\
\text { Update } \\
\text { Construct } \\
\text { Reflective } \\
\text { Simulation } \\
\text { Hyperlinked } \\
\text { Non-immersive } \\
\text { contextual } \\
\text { Immersive virtual }\end{array}$ & $\begin{array}{l}\text { Visibility and accessibility } \\
\text { Visualise content in different } \\
\text { ways } \\
\text { Access content in different } \\
\text { ways } \\
\text { Manipulatability and } \\
\text { annotatability } \\
\text { Construct content } \\
\text { Make notes } \\
\text { Creativity and combinability } \\
\text { Create new content by } \\
\text { combining media } \\
\text { Experimentation and testing } \\
\text { Run a simulation }\end{array}$ \\
\hline
\end{tabular}

Table 5: Interactive constructs

So despite the criticism levelled by Rose (1999), for those actively developing CEL applications, a resurgence of interest in the value of interactivity can only help to ensure the quality of the products are ensured. As advocated by Reeves (1999), the promise of effective interactivity will be achieved by focusing on the ways in which we can make the applications work better rather than relying on empirical research or technological developments to prescribe the solutions.

\section{And moving online?}

In the last few years, the word interactivity has tended to be applied more frequently to the facilities afforded through computer mediated communication and the increased promotion of online learning and web based training. Regardless of the computer based medium, any interaction between learners and learners or learners and content cannot be assumed to be an automatic facility of the computer based medium. Rather, considerable design effort must continue to be placed on the ways in which learners will both adopt and adapt to the exchange of ideas and engagement with content through computer mediated resources. 
Moving to an online environment, with the perceived benefits of human to human communications, can from one perspective be seen to diminish the importance of overt human to computer interactions. However, I maintain that it is the engagement and learning that interactivity can enhance that is the critical component of any computer facilitated learning artefact and that this interactivity needs constant maintenance regardless of the medium of delivery.

\section{Conclusions}

The application of the term interactivity to CEL applications has assumed to imply an implicit level of effectiveness and learning guarantee. However, despite attempts to provide a context for interactivity through taxonomies, levels and dimensions, there remains a level of mystery about its function and purpose. By revisiting the foundations for educational practice - the theories of learning - a wide range of potential interactive constructs can be derived which should enhance the learning process, whether by simple physical interaction or through more complex and implicit cognitive engagement.

In many ways it appears that too little research has been undertaken to actually determine what is happening during the interactive experience. Much of the praise for this has come from the popular press that has adopted the term as one of the positive indicators of a productive digital future. Similarly, it is not simply a case that we need to move ahead with the technology as promoted by Kearsley \& Shneiderman (1999).

It is not the technology that is at fault but the implementation of the interactivity demanded by users. Indeed, computer based interactivity is not a promise unfulfilled, but rather a promise not yet realised.

\section{References}

Aldrich, F., Rogers, Y. \& Scaife, M. (1998). Getting to grips with "interactivity": Helping teachers assess the educational value of CD-ROMs. British Journal of Educational Technology, 29(4), 321-332.

Anderson, J. (1976). Language, Memory and Thought. Hillsdale, NJ: Erlbaum Associates.

Argyris, C. \& Schon, D. (1974). Theory in Practice. San Francisco: Jossey-Bass.

Atkinson, R. C. (1972). Ingredients for a theory of instruction. American Psychologist, 27, 921-931.

Ausubel, D. (1963). The Psychology of Meaningful Verbal Learning. New York: Grune \& Stratton. 
Bandura, A. (1971). Social Learning Theory. New York: General Learning Press

Bower, G.H. \& Hilgard, E.R. (1981). Theories of Learning. (5th Edition). New York: Prentice Hall.

Brown, J.S. \& Van Lehn, K. (1980). Repair theory: A generative theory of bugs in procedural skills. Cognitive Science, 4, 379-426.

Bruner, J. (1966). Toward a Theory of Instruction. Cambridge, MA: Harvard University Press.

Card, S., Moran, T. \& Newell, A. (1983). The Psychology of Human-Computer Interaction. Hillsdale, NJ: Erlbaum.

Carroll, J.M. (1990). The Nurnberg Funnel. Cambridge, MA: MIT Press.

Craik, F. \& Lockhart, R. (1972). Levels of processing: A framework for memory research. Journal of Verbal Learning \& Verbal Behavior, 11, 671-684.

Cronbach, L. \& Snow, R. (1977). Aptitudes and Instuctional Methods: A Handbook for Research on Interactions. New York: Irvington.

Cross, K.P. (1981). Adults as Learners. San Francisco: Jossey-Bass.

DeBono, E. (1967). New Think: The Use of Lateral Thinking in the Generation of New Ideas. New York: Basic Books.

Festinger, L. (1957). A Theory of Cognitive Dissonance. Stanford, CA: Stanford UniversityPress.

Gagné, R. (1985). The Conditions of Learning. 4th Edition. New York: Holt, Rinehart \& Winston.

Gardner, H. (1993). Multiple Intelligences: The Theory in Practice. NY: Basic Books.

Gibson, J.J. (1966). The Senses Considered as Perceptual Systems. Boston: Houghton Mifflin.

Guthrie, E.R. (1930). Conditioning as a principle of learning. Psychological Review, $37,412-428$.

Hull, C. (1943). Principles of Behavior. New York: Appleton-Century-Crofts.

Jonassen, D. (1988). Instructional Designs for Microcomputer Courseware. Hillsdale, NJ: Lawrence Erlbaum.

Kearsley, G. (1999). Explorations in Learning \& Instruction: The Theory Into Practice Database. http:/ / www.gwu.edu/ tip/ [10August 1999].

Kearsley, G. \& Shneiderman, B. (1999). Engagement Theory: A framework for technology-based teaching and learning. http: / / www.gwu.edu/engage.htm [10 August 1999].

Knowles, M. (1984). Andragogy in Action. San Francisco: Jossey-Bass

Landa, L. (1974). Algorithmization in Learning and Instruction. Englewood Cliffs, NJ: Educational Technology Publications. 
Lave, J., \& Wenger, E. (1990). Situated Learning: Legitimate Peripheral Participation. Cambridge, UK: Cambridge University Press.

Mager, R. (1988). Making Instruction Work. Belmont, CA: Lake Publishing Co.

Maltzman, I. (1960). On the training of originality. Psychological Review, 67(4), 229242.

Mandel, T. (1997). The Elements of User Interface Design. New York: John Wiley \& Sons.

Marton, F., Hounsell, D. \& Entwistle, N. (1984). The Experience of Learning. Edinburgh: Scottish Academic Press.

Merrill, M.D. (1983). Component Display Theory. In C. Reigeluth (ed.), Instructional DesignTheories and Models. Hillsdale, NJ: Erlbaum Associates.

Miller, G.A. (1956). The magical number seven, plus or minus two: Some limits on our capacity for processing information. Psychological Review, 63, 81-97.

Newell, A. (1990). Unified Theories of Cognition. Cambridge, MA: Harvard University Press.

Newell, A. \& Simon, H. (1972). Human Problem Solving. Englewood Cliffs, NJ: Prentice-Hall.

Paivio, A. (1986). Mental Representations. New York: Oxford University Press.

Piaget, J. (1929). The Child's Conception of the World. NY: Harcourt, Brace Jovanovich.

Plowman, L. (1996a). Narrative, linearity and interactivity: making sense of interactive multimedia. British Journal of Educational Technology, 27(2), 92-105.

Reeves, T.C. (1999). A research agenda for interactive learning in the new millenium, in B. Collis \& R. Oliver (Eds) Proceedings of EdMedia 1999. Charlottesville, VA: Association for the Advancement of Computing in Education.

Reigeluth, C. (1992). Elaborating the elaboration theory. Educational Technology Research \& Development, 40(3), 80-86

Rogers, C.R. (1969). Freedom to Learn. Columbus, OH: Merrill.

Romiszowski, A.J. (1986). Developing Auto-Instructional Materials. London: Kogan Page.

Rose, E. (1999). Deconstructing interactivity in educational computing. Educational Technology, 39(1), 43-49.

Rumelhart, D. \& Norman, D. (1978). Accretion, tuning and restructuring: Three modes of learning, in. J.W. Cotton \& R. Klatzky (Eds), Semantic Factors in Cognition. Hillsdale, NJ: Erlbaum.

Salomon, G. (1979). Interaction of Media, Cognition, and Learning. San Francisco: Jossey-Bass. 
Scandura, J.M. (1973). Structural Learning I: Theory and Research. London: Gordon \& Breach.

Schoenfeld, A. (1985). Mathematical Problem Solving. New York: Academic Press.

Schank, R.C. (1982). Dynamic Memory: A Theory of Reminding and Learning in Computers and People. Cambridge University Press.

Schwier, R. \& Misanchuk, E. (1993). Interactive Multimedia Instruction. Englewood Cliffs, NJ: Educational Technology Publications.

Shedroff, N. (1994). Information Interaction Design: A Unified Field Theory of Design. http:/ / www.nathan.com/thoughts/unified / [11 April 2000].

Sims, R. (1997). Interactivity: A Forgotten Art? Computers in Human Behavior, 13(2), 157-180.

Sims, R. (1999). Interactivity and narrative: Strategies for effective learning, in B. Collis \& R. Oliver (Eds) Proceedings of EdMedia 1999. Charlottesville, VA: Association for the Advancement of Computing in Education.

Skinner, B.F. (1950). Are theories of learning necessary? Psychological Review, 57(4), 193-216.

Spiro, R.J., Feltovich, P.J., Jacobson, M.J., \& Coulson, R.L. (1992). Cognitive flexibility, constructivism and hypertext: Random access instruction for advanced knowledge acquisition in ill-structured domains. In T. Duffy \& D. Jonassen (Eds.), Constructivism and the Technology of Instruction. Hillsdale, NJ: Erlbaum.

Sternberg, R.J. (1977). Intelligence, Information Processing, and Analogical Reasoning. Hillsdale, NJ: Erlbaum.

Sticht, T.G. (1976). Comprehending reading at work. In M. Just \& P. Carpenter (Eds), Cognitive Processes in Comprehension. Hillsdale, NJ: Erlbaum.

Thorndike, E. (1913). Educational Psychology: The Psychology of Learning. New York: Teachers College Press.

Tolman, E.C. (1932). Purposive Behavior in Animals and Men. New York: AppletonCentury-Crofts.

Vygotsky, L.S. (1962). Thought and Language. Cambridge, MA: MIT Press.

Wertheimer, M. (1959). Productive Thinking (Enlarged Edition). New York: Harper \& Row.

Rod Sims

School of Multimedia and Information Technology

Southern Cross University

rsims@scu.edu.au

http: / / multimedia.scu.edu.au

Phone: (02) 66593310 Fax: (02) 66593612 